\title{
The Influences of Multinational Corporation's Headquarters and Host Country Cultures on Foreign Subsidiaries' Management Styles
}

\author{
Yezdi H. Godiwalla ${ }^{1}$ \\ ${ }^{1}$ Management Department, College of Business and Economics, University of Wisconsin-Whitewater, Whitewater, \\ Wisconsin, USA. \\ Correspondence: Yezdi H. Godiwalla, Management Department, College of Business and Economics, University of \\ Wisconsin-Whitewater, Whitewater, Wisconsin, USA.
}

Received: July 19, 2016

Accepted: August 9, 2016

Available online: August 17, 2016

doi:10.11114/aef.v3i4.1815

URL: http://dx.doi.org/10.11114/aef.v3i4.1815

\begin{abstract}
The approach of the traditional top down total directives from an international (or, multinational, global or transnational) corporation's corporate headquarters to its foreign subsidiary units about the choice of the unit's management styles and organizational culture and internal practices is not effective. Instead, international firms must allow the units to develop their own management styles and organizational culture to suit their respective host country environments, religion, social, work and operating cultures. Please see Notes 1 and 2 for definitional issues. Host country cultures have strong influences on a foreign subsidiary unit's organizational culture in as much as the headquarters' influence can be somewhat blended and tempered. Host country nationals employed in the foreign subsidiary unit, while they are loyal to the generalized, core global corporate philosophy and values from the headquarters, they can be expected to be more intense in their feelings of their national patriotism and values. The foreign subsidiary's management styles and organizational culture are more likely to closely adhere to the host country's values and temperament. The moral of the issue is that the headquarters must delegate to the foreign subsidiary the choices of management style, method of management and the internal organizational culture and processes that pervade its internal workings. The corporate headquarters' influences are likely to hold stronger for the specific values, processes and norms of industry, technical, commercial, and administrative so long as they do not conflict with the host country's core cultural values, norms and tradition and practices.
\end{abstract}

Keywords: Multinational corporation headquarters' influence on foreign subsidiaries, subsidiary management styles.

\section{Introduction}

It used to be customary for a multinational corporation (MNC), or, for the purposes of this article, an organization which has significant operations across many countries, to use their templates of management styles, organizational structures, cultures and practices to organize their foreign subsidiary units, often not giving a fuller consideration to their respective host countries' cultures, religions and operating environments. This approach led to ineffective foreign subsidiary units which had to struggle to decide on an identity that would simultaneously meet the headquarters expectations and local societal aspirations and operating conditions. Please see Notes 1 and 2 for definitional issues.

The purpose of this paper is to provide the other side of the story: to seriously consider host countries' cultural (including religious) influences upon society in developing the subsidiaries' particular management styles and organizational cultures. The paper presents two figures that use the idea that the effective management style of a foreign unit depends, in part, upon its host culture and environment. The paper draws from Greek mythology in developing four effective management styles and organizational cultures for foreign units.

The importance of the host country's particular culture on the choice of effective management styles and organizational culture is here considered. The focus on the local influences has the a-priori, predetermining force on the choice of the effective management style as derived from the Greek mythology. In using this argument, the assumption is that in choosing the dominant logic in the management style, one places a greater importance of the local host country influences on a subsidiary's management style choice than the directives of the headquarters. The template used by the headquarters is held not so much inviolate as less influential than the local pressures. In times of pressures of stiff competition or rapid growth of the foreign subsidiary, it can be that the foreign subsidiary may have to reinvent its 
management style and organizational culture. This pressure for a foreign subsidiary to rapidly change in order to be more competitive would make for the headquarters impatience. In this scenario, the headquarters may have a greater justification in dictating a rapid response model for its foreign subsidiary. There can be other reasons for headquarters' concern for imputing the choice of the management styles and posture, such as for example, global cost cutting and re-structuring, and, this can be more a concern for the headquarters to have a faster re-organization and thus the process will be headquarters driven.

\section{The Importance of Organizational Culture to Managing in Cultural Diversity and Dynamic Environments}

Changing global environments bring pressures of increasing and often unpredictable competition, new technologies of product design, engineering, manufacturing/operations, marketing, and information, (Michailova, Mustaffa, and Barner-Rasmussen, 2016). To effectively manage a large international firm with many subsidiary units in dynamic and diverse country cultures, the top management should ensure that its organizational culture has the following attributes: (1) top management leadership supports the suitable or right culture for its global innovation and long term needs (Berry, 2015; Schein, 1985); (2) strategy is compatible with culture (and vice versa) as they are needed to move the organization through change (Galphin, 1996; Harrison and Beyer, 1993; Morgan, 1993; and Flannagan, 1995); and (3) culture should be an asset to the organization, not a liability, i.e., the top management should be able to modify and even change it to deal in changing times (Brief, 1996; Flannagan, 1995; Reger, et.al., 1993; Trice and Beyer, 1993).

\section{Organizational Culture}

Organizational culture is an intangible aspect of the institutionalization of the ways of a working organization. It represents the core set of values, implicit rules, norms, processes, procedures and methods of doing most activities that encompass not only important decisions but also day-to-day decisions and conduct by the members (Deal and Kennedy, 1983). To become accepted as a member by the organization it is imperative that one has to be perceived by other members as having fully accepted and practicing the core values, assumptions and rules of conduct of the organization (Hitotsuyanagi-Hansel, Froese, and Pak, 2016) . Thus, compliance to organizational culture is expected of its members, and behaviors that are departures from the organizational culture are frowned upon (Schein, 1985).

\subsection{Force of Culture}

Organizational culture has a force of its own. It is, so to speak, the religion of an organization. It is unique to the organization. Its force, because of the shared values, equips a member to behave in accordance with the culture and, thus, gives him a sense of security. An individual, whose own values are contrary to those of the organization, would not, only not fit in with the organization, but he would also be shunned by others in the organization.

\subsection{Dysfunctionality of an Ill-Suited Organizational Culture}

An older, inveterate organizational culture can become a liability to the organization. This is particularly true if particularly if the older, inveterate organizational culture is not valid in the changing environment and if the demands upon the organization are changing and intensifying, then the older, inveterate organizational culture would be an even a greater problem. Further, because it is difficult to change organizational culture in a short period of time, it is even more challenging for its top management to manage in these circumstances: the dysfunctional nature of the culture and the un-changeability of the culture in the short run.

\subsection{Organizational Culture as Strategy, and, Innovation Transfer Process}

The notion of organizational culture being synonymous with the organization strategy is interesting. With the intense competitive drive among global competitors, innovation strategy can be the dominant logic for corporate strategy. While an MNC headquarters may drive to transfer its management approaches (styles, organizational culture) to its foreign subsidiaries, however, as Berry states (2015) that "the combining managerial knowledge transfers with local subsidiary investments in innovation is shown to boost the performance of foreign operations located in leading technology countries, suggesting that the prior experiences, connections, and knowledge of expatriate managers, can be particularly useful in managing new knowledge generated in these countries. Overall, this paper extends our understanding of knowledge management within MNCs by exploring when transfers of parent technological and managerial knowledge are more likely to improve the performance of foreign operations in increasingly globally competitive industries. Organizational response (be it proactive or reactive) to environmental events may indeed be viewed as a culturally initiated endeavor." (Berry, 2015)

A strategic response may thus be an organizational cultural action. This can be interesting to view as Timothy Galphin (1996) indicates the organizational culture, as it relates to organizational change, embodies issues of: rules and policies, goals and measurement, customs and norms, training, ceremonies and events (including rituals), management behaviors, rewards and recognition, communications, physical environment, and organizational structure. These components of organizational culture reveal the manifestations of a firm's organizational culture. 


\section{Religion, Organizational Culture and International Management}

A large international firm with many foreign subsidiary units operating in many diverse and dynamic country cultures would benefit from following the concept of strategic and cultural flexibility for its subsidiaries. The host countries' religions have strong influence upon its culture and subcultures. And often the tenets of a religion flow to become important values to be taken for granted in a society's culture, particularly in the case of older culture countries (Hinnells, 1973; Prabhuda, 1978; and Rice, 1978). Tracing even earlier, people revered nature, idols and spirits of their family in order to protect themselves against evil (Gaer, 1957). Religion has had impact upon strategies to change the history of a country, e.g. Joan of Arc (Brooks, 1990).

Thus, religion is the set of deep roots of a country's culture. It relates a human being to his beginnings, present and future. It gives him meaning for his place in society. Collectively, it is the mainstay of a society's values (Berry 2015; Gaer, 1956; Martin, 1991; Rice, 1978). Different cultures have different influences of their religions. It is important to match the organizational culture of a foreign subsidiary not only to its host country cultures but also to its religions (Handy, 1995).

Just as a person should analyze himself and, ideally, should join an organization to which he is best suited (O'Reilly, et.al., 1991), so also a foreign subsidiary should choose its culture best fitting the host country's dominant culture(s). And, it should match the culture in the context of its industry, technologies and markets (Chatman and Jehn, 1994).

\subsection{The Dual Orientations}

The dual orientations of a foreign subsidiary unit's orientation to its: (a) host country cultures, along with the similar cultures of the nearby countries in the host country's region, and (b) the MNC corporate or headquarters' global organizational culture which would often make additional demands upon it. The foreign subsidiary management has to contend with these two often conflicting forces. Its skill in combining the two forces to the advantage of the foreign subsidiary unit is the key to, not only its sanity, but also the additional vigor that it would derive for the pursuit of its generalized longer term objectives, specific shorter term goals, and its subsidiary unit strategy.

Further, the foreign subsidiary unit's top management has to perform the multiple roles in this context (between the MNC headquarters, and, the local host country and regional environments) of: (a) coordination, (b) bridge, (c) communication, (d) strategic management, of the foreign subsidiary unit within the broad economic, strategic and social framework set by the corporate headquarters, and (e) support legitimate aspirations and needs of the people of its unit which it leads and which it must effectively represent to the top management at the firm's headquarters (Morgan, 1993).

The maturity of the top management at the headquarters and all subsidiary units is a key factor in achieving harmony, empathy and analyses to determine how much strategic and operational diversity to encourage and how much other of these same to discourage, (Jiang, Holburn, and Beamish. 2016). The arts and skills of leadership at each of these top managements bear testimonies of successes at each center of performance: at country unit, regional and global firm levels (Kono, 1994).

Another important consideration for the combined performance of the $\mathrm{MNC}$ and foreign subsidiaries is the degree of diversification. Lo (2016) studied the impact of the degree of the (business) diversification of the MNC and the advantageous transfer of the technology and innovation from the MNC headquarters to the foreign subsidiary units. The study explored the intra-MNC advantageous transfer from the headquarters organization to its foreign subsidiaries units and it analyzed the quality of impact of the transfer on the competitiveness and performance wrought from the foreign subsidiary units, "and further examines the moderating effect of the international diversification. The empirical results support the existence of an invert-U relationship between intra-MNE advantage transfer and subsidiary performance. In addition, findings support the moderating effect of international diversification of intra-MNE advantage transfer on subsidiary innovativeness and performance" (Lo, 2016). The study concluded that both very low and very high degrees of MNC diversification adversely affect the quality of advantageous transfer of technology and innovation from the headquarters to the foreign subsidiary units, and, subsequently, foreign subsidiary units' performance. Medium degree of MNC diversification, however, had more advantageous or beneficial transfer of technological innovation from the headquarters to the foreign subsidiary units and, consequently, foreign subsidiary units' performance. An additional consideration is that many MNCs have a widely networked technological innovation programs among its headquarters and its foreign subsidiary units. In these scenarios, the issue of technological and innovation transfers is not from the headquarters to the foreign subsidiary units, but collectively from all parts of the MNC to a particular foreign subsidiary unit. Examples of a widely networked innovation programs include: the development of a "next" generation Tide clothes washing detergent jointly developed by Procter and Gamble's Japanese subsidiary unit and its headquarters at Cincinnati, and, the first color television developed by Philips was not done by its headquarters in Eindhoven, The Netherlands, but mainly by its foreign subsidiary Canadian unit. These innovated product designs and their accompanying technologies were then transferred to the rest of the organizations. 
The religious diversities that in part engender cultural diversities among countries and regions become a key underlying factor in understanding the tenets of effective global management. Because different host country cultures of a global firm are different, it must adopt different host country subsidiary unit's management styles and organizational cultures. Religion is here considered as a starting, foundation point of culture.

In the article, "Emplanted decision-making", (International Executive, 1983), the author presents the findings on the influence of US MNCs on the choice of management styles and decision-making in their UK foreign subsidiaries. The main issue investigated is whether or not an MNC, whose headquarters is in another country, may successfully "implant its management style on a foreign subsidiary". A headquarters is more likely to successfully transfer some of its management techniques rather than management philosophy. Therefore, the transference of organization's standard operating procedures, organizational structure and other formal features is more likely to be transferred, if just partially. The article is very eloquent about the issues it has espoused, such as its arguments cited here: "Attention is therefore focused on less formalized elements, in this case the process of making decisions. Three degrees of formality in decision groups were identified: working groups assembled informally and temporarily, special committees formally constituted but terminated after the decision was made and standing committees. The time dimension of decisions was broken down into two parts: gestation time-- the period from first inception of a subject to when it is recognized as a topic for decision, and process time that required is to reach a decision. Among the U.S. firms two decisions involved very long gestation periods due to special problems which prevented management action" (International Executive, 1983). In so reviewing these issues, one is led to believe that the organizational situation and the conditions of the focused expectations imputed on the foreign subsidiary would influence its management style and organizational culture.

\section{Host Country Culture and Effective Foreign Subsidiary's Top Management Style and Organizational Culture}

Religions and cultures of countries in the region of the host country may influence the very ways people live in those countries. It is therefore necessary to first understand the basis of the culture of a host country and those of the nearby countries of the region, and then deduce the broadly stated headquarters' philosophy and values, and then finally, evolve the correct management style and organizational culture of the foreign subsidiary. The chosen management style and organizational culture must be a good balance that would simultaneously satisfy the major tenets of the local and regional cultural values and norms on the one hand, and the corporate headquarters' philosophy and values, on the other hand.

This basic rationale or concept is applied in the two figures. Figure 1 is a model of how factors influence the organizational culture of a subsidiary unit in a foreign country culture. And Figure 2 portrays the same basic concept, i.e., the choice of the foreign unit's management style and organizational culture should, in part, depend upon its host country environment and culture; this is in addition to, as we have argued before, the global firm's basic organizational culture.

\subsection{Figure 1}

The figure emphasizes the importance of the host country and other countries in the region as they have an influence upon the choice of effective subsidiary unit's management style and culture. The dimensions of organizational culture (bottom cell in Figure 1) are derived from Timothy Galphin (1996). The rigidity or looseness of rules and policies, the goal intensity and detail, the folk lore and norms, the emphasis of education, and the styles of management, rewards, communication, climate and culture of the subsidiary organization are important manifestations of the subsidiary organization. And these should be determined not only by directives and specifications by the MNC corporate headquarters but also by the culture and norms of the host country and its local region. 


\begin{tabular}{|l|l|}
\hline \multicolumn{1}{|c|}{ HOST COUNTRY'S: } & \multicolumn{1}{c|}{ LOCAL REGION'S: } \\
\hline - Sociology, anthropology & \\
- Religion(s) & - Sociology, anthropology \\
- Natural resources & - Religion(s) \\
- State of development of industry, agriculture & - Natural resources \\
- Industry pressures & - State of development of industry, agriculture \\
\hline
\end{tabular}

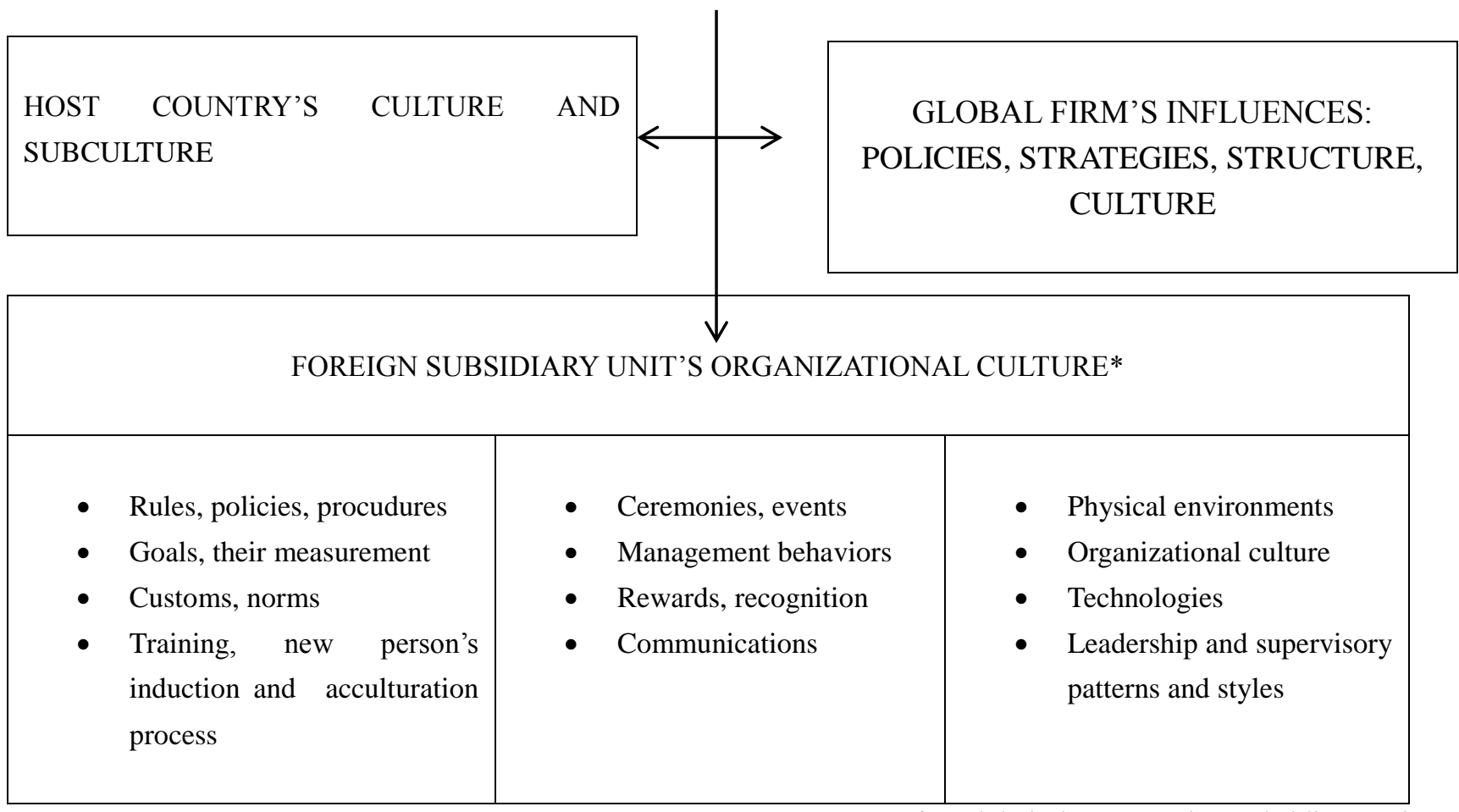

Figure 1. A Model of How Factos Influence The Organizational Culture of A Global Firm'S Foreign Subsidiary Unit

* Adapted from Galphin, T. (1996). Connecting culture to organizational change. HR Magazine. 41, 84-86.

Description: The model emphasizes the influences of the sociological and environmental aspects of the foreign subsidiary's host country and the nearby countries in the region of the host country. These influences are vital to the foreign subsidiary unit's internal culture and management style.

\subsection{Figure 2}

The four top management styles and organizational cultures, which are derived from Greek mythology, are developed from the works of Charles Handy (1995). The four types of management styles are: (1) Club (or Zeus), or close knit network with power kept centrally, (2) Role (or Apollo), or a bureaucratic machine with clearly specified job descriptions for all roles, (3) Task (or Athena), or a network of resourceful and intensely focused people who concentrate their joint skills upon specific problems and projects, and, (4) Existential (Dionysus), or high professionalism, with strong emphasis on the individual specialist, not the organization or even the team.

Each of these four styles can only be suitable for a specific host country culture and environment. The specific country cultures to which the four styles are correspondingly suited are listed at the bottom of Figure 2. Each of these styles portrays certain particular assumptions, values and priorities. Each can be very effective in a particular suitable environment, but not effective in a very different environment. 


\begin{tabular}{|c|c|c|c|c|}
\hline $\begin{array}{l}\text { Characteristics of } \\
\text { Organizational } \\
\text { Cultural Orientation: }\end{array}$ & $\begin{array}{c}\text { FOUR MGMT } \\
\text { CLUB } \\
\text { Zeus }\end{array}$ & $\begin{array}{l}\text { STYLES } \\
\text { ROLE } \\
\text { Apollo }\end{array}$ & $\begin{array}{l}\text { USING } \\
\text { GREEK } \\
\text { TASK } \\
\text { Athena }\end{array}$ & $\begin{array}{c}\text { MYTHOLOGY } \\
\begin{array}{c}\text { EXISTENTIAL } \\
\text { Dionysus }\end{array}\end{array}$ \\
\hline $\begin{array}{l}\text { 1. Innovation, risk } \\
\text { taking: }\end{array}$ & Vital & A weakness & Creativity & $\begin{array}{c}\text { Only if specialist } \\
\text { is a risk taker }\end{array}$ \\
\hline $\begin{array}{l}\text { 2. Attention to } \\
\text { details: }\end{array}$ & $\begin{array}{l}\text { Only on critical } \\
\text { details }\end{array}$ & $\begin{array}{l}\text { High focus on } \\
\text { process }\end{array}$ & High attention & $\begin{array}{c}\text { High } \\
\text { professionalism }\end{array}$ \\
\hline $\begin{array}{l}\text { 3. Outcome } \\
\text { orientation: }\end{array}$ & Main emphasis & Low focus & $\begin{array}{l}\text { Solutions to } \\
\text { problems }\end{array}$ & $\begin{array}{l}\text { Focus on } \\
\text { specialist's } \\
\text { passions, pursuits }\end{array}$ \\
\hline $\begin{array}{l}\text { 4. People } \\
\text { orientation: }\end{array}$ & $\begin{array}{l}\text { Intense for top } \\
\text { management }\end{array}$ & $\begin{array}{c}\text { Low. They are } \\
\text { treated as parts } \\
\text { of machine } \\
\text { bureaucracy }\end{array}$ & $\begin{array}{l}\text { Youth, } \\
\text { brilliance }\end{array}$ & $\begin{array}{l}\text { Focus on the } \\
\text { individual } \\
\text { specialist }\end{array}$ \\
\hline $\begin{array}{l}\text { 5. Team } \\
\text { orientation }\end{array}$ & $\begin{array}{c}\text { Well-knit top } \\
\text { management team }\end{array}$ & $\begin{array}{l}\text { Bureaucratic } \\
\text { committees }\end{array}$ & $\begin{array}{l}\text { Purposeful } \\
\text { command } \\
\text { teams }\end{array}$ & $\begin{array}{c}\text { Mutual respect } \\
\text { for peers and their } \\
\text { qualities }\end{array}$ \\
\hline 6. Aggressiveness & $\begin{array}{l}\text { Entrepreneurial, } \\
\text { prospective, } \\
\text { risk-taking, } \\
\text { proactive }\end{array}$ & $\begin{array}{c}\text { A weakness, } \\
\text { slow, reactive, } \\
\text { cautious }\end{array}$ & $\begin{array}{l}\text { A strength, } \\
\text { progressive, } \\
\text { focused }\end{array}$ & $\begin{array}{l}\text { Not a strength, } \\
\text { Slow }\end{array}$ \\
\hline 7. Stability: & $\begin{array}{l}\text { Important at the } \\
\text { top }\end{array}$ & $\begin{array}{l}\text { High need for } \\
\text { predictability, } \\
\text { steadiness }\end{array}$ & Very low & $\begin{array}{l}\text { Search for } \\
\text { security, assured } \\
\text { stability, } \\
\text { steadiness }\end{array}$ \\
\hline $\begin{array}{l}\text { 8. Types of host } \\
\text { country cultures } \\
\text { and environments } \\
\text { for which the } \\
\text { management } \\
\text { style is best } \\
\text { suited: }\end{array}$ & $\begin{array}{l}\text { Highly political, } \\
\text { economic, } \\
\text { marketing risk } \\
\text { taking; need for } \\
\text { bold, quick } \\
\text { decision making; } \\
\text { culture emphasizes } \\
\text { competence }\end{array}$ & $\begin{array}{l}\text { Stable markets } \\
\text { in which the } \\
\text { firm is well } \\
\text { established; } \\
\text { culture } \\
\text { emphasizes } \\
\text { seniority }\end{array}$ & $\begin{array}{c}\text { Competitive, } \\
\text { sophisticated, } \\
\text { dynamic } \\
\text { environment }\end{array}$ & $\begin{array}{l}\text { Benign, stable } \\
\text { environments and } \\
\text { cultures }\end{array}$ \\
\hline
\end{tabular}

Figure 2. Host Country's Cultures and Subsidiary Unit's Management Styles

Description: The four management styles derived from Greek mythology, Zeus, Apollo, Athena and Dionysus, are here used as a template for the four top management approaches. Further, the strong influence of the foreign subsidiary unit's host country's cultures upon the foreign subsidiary unit is also here considered as the top management of the foreign subsidiary unit evolves its effective management style.

\section{The Issues of the Article Apply to Any Type of International Firm}

The issues of the article have wide applications to all firms which have significant cross country broader corporate activities, including supply chain, marketing, assembly and operations, distribution. It is not so critical to the discussions of this article whether the organization is a domestically-oriented exporting firm, or an international, or multi-domestic, or multinational, or global, or transnational firm. Please see Note 1 for definitional issues. In this way, we can discuss the issues of the article without becoming encumbered with definitional aspects as we progress with the discussions of the topics of the article.

Growth is an important consideration in the progression of increasing internationalization of an international organization. That is to say, an international organization focuses on growth through diversifying its country or regional markets rather than diversify its products or technologies or businesses. In so doing it gets to grow with the same technologies and keep intensifying its knowledge of that technology. It then has to focus on learning cultural differences among countries. It has to also adapt its value chain to the specific operation conditions of the countries it seeks to enter.

\section{Conclusions}

International, multi-domestic, global or transnational firms often are used to delegate downwards to their foreign subsidiaries their management styles and organizational cultures. However, it is important to also realize the influences of a host country and its nearby host region (or countries in that part of the world that may share some or many similar traits of cultures) in evolving the suitable management style and organizational culture of the foreign subsidiaries, (Grewal, 
Kumar, Mallapragada, and Saini, 2013).

In their study, Grewal, Kumar, Mallapragada, and Saini (2013) have reviewed the effects of the "inherited parent firm knowledge" on the quality of benefits on the foreign subsidiary units. From their study, they make a case that the nature and the intensity of benefits on the foreign subsidiaries differ from one subsidiary unit to another subsidiary unit, and that the transfers of knowledge and technological skills from the parent firm to its foreign subsidiaries in fact provide differing levels of benefits to its foreign subsidiary units.

The authors, Grewal, Kumar, Mallapragada, and Saini (2013), argue that the advantages to foreign operation vary among the foreign subsidiary units, depending on the infrastructure and technological capabilities of the host country and the type of knowledge transferred. They cite in their study the results from a comprehensive panel of U.S. MNCs, "using fixed effects and system general method of moments (GMM) models to correct for endogeneity (or, evolved from within) issues, show that inherited parent firm knowledge is not equally valuable in all countries." (Grewal, Kumar, Mallapragada, and Saini, 2013).

The foregoing argument provided by Grewal, Kumar, Mallapragada, and Saini (2013) is worthwhile considering the complexities of diverse cultures of sister foreign subsidiaries as they can affect the internal activities of a particular foreign subsidiary operating in its host country environment. There is a further quote from Grewal, Kumar, Mallapragada, and Saini (2013) on this issue which provides us with a flavor of their views, "The transfer of technological knowledge is value-creating when home country innovation dominates and when parent firm knowledge is transferred to foreign operations in lagging technology countries (when foreign technology dominates There is the usual stronger influence of host country cultures on the management style, culture, processes of a foreign subsidiary, while the influence of the headquarters may be somewhat lesser, limiting to the transfer of technologies and the culturally bland core corporate values and philosophies." (Grewal, Kumar, Mallapragada, and Saini, 2013).

The local host country nationals, who are employed in a foreign subsidiary, will be sensitive to both, looking towards the corporate headquarters' values and procedures, and, they would be, or at least want to be perceived to be in the eyes of the local population, patriotic to the host country. The host country people can be expected to be loyal to their own country's national values, cultures, norms and customs.

With significant cross country border activities and operations, an international organization of any type, with its diverse activities and complex business involvements, would be better off decentralizing its decision making from the headquarters to its foreign subsidiary units. This delegation of strategic and operational decision making would significantly empower the foreign subsidiary units in ways unlikely if the corporate headquarters were to regain full control of all decision making.

The effective management styles and culture of a foreign subsidiary unit depend, in part, upon its host country culture and environment, as they are portrayed in Figure 2. These issues are main logics of management decision making. The essential rationale for strategic and operating decision making thus becomes the basis of the dominant management style.

The major ideas for effectively operationalizing the four, so to speak, "Greek-Gods-based" styles are summarized for easy and ready reference in the following matrix. The approach of the matrix is that if a host country's particular culture and operating environment is of a certain type, then the effective management style for that country would be as specified in the matrix.

This matrix approach follows the contingency approach of management. This implies that it does not appear to have a single, over-arching, higher level of abstraction, monolith theory of management. However, it is possible to have multiple, mid-level of abstraction, contingency mini-theories of management. These min-theories are dependent on the major circumstances. Depending on the nature of the major circumstances, the mini-theories predict the general effective management approaches. These mini-theories could be integrated in a loose way or they may just remain somewhat disconnected. 
If the host country culture and operating environment is:

1. High risk, politically, economics and marketing; with power kept centrally

2. Firm is well established in stable host culture with clear role/job descriptions

3. Sophisticated, dynamic, advanced environments and cultures of peers focusing on problems (as in a consulting firm)

4. Benign, stable, predictable culture
Then the effective management style and organizational culture would be:

\section{References}

Berry, H. (2015). Knowledge inheritance in global industries: The impact of parent Firm knowledge on the performance of foreign subsidiaries. Academy of Management Journal, 58(5), 1438-1458. http://dx.doi.org/10.5465/amj.2013.0724

Brief, A. P., Guzzo, R. A., \& Schneider, B. (1996). Creating a climate and culture for sustainable organizational change. Organizational Dynamics, 7-19.

Brooks, P. S. (1990). Beyond the Myth, The Story of Joan of Arc. New York, NY: J. B. Lippincott.

Chatman, J. A., \& Jehn, K. (1994). Assessing the Relationship Between Industry Characteristics and Organizational Culture: How Different Can You Be. Academy of Management Journal, 552-53. http://dx.doi.org/10.2307/256699

Deal, T. E., \& Kennedy, A. A. (1983). Culture: A New Look Through Old Lenses. Journal of Applied Behavioral Science, 501-509. http://dx.doi.org/10.1177/002188638301900411

Flannagan, P. (1995). The ABCs of Changing Corporate Culture. Management Review, 57-61.

Gaer, J. (1956). How the Great Religions Began. New York, NY: Dodd, Mead \& Co.

Galphin, T. (1996). Connecting Culture to Organizational Change. HR Magazine, 41, March, 84-86.

Grewal, R., A., Kumar, M. G., \& Saini, A. (2013). Marketing Channels in Foreign Markets: Control Mechanisms and the Moderating Role of Multinational Corporation Headquarters-Subsidiary Relationship. Journal of Marketing Research, 50(3), 378-398. http://dx.doi.org/10.1509/jmr.11.0487

Handy, C. (1995). Gods of Management, The Changing Work of Organizations. New York, NY: Oxford University Press.

Hinnells, J. R. (1973). Persian Mythology. London, UK: Hamlyn Publishing Group.

Hitotsuyanagi-Hansel, A., F., Froese, J., \& Pak, Y. S. (2016). Lessening the divide in foreign subsidiaries: The influence of localization on the organizational commitment and turnover intention of host country nationals. International Business Review, 25(2), 569-578. http://dx.doi.org/10.1016/j.ibusrev.2015.09.011

International Executive. (1983). Emplanted decision-making. 25(3), 7-9.

Jiang, G. Holburn, F., \& Beamish. P. W. (2016). The spatial structure of foreign subsidiaries and MNE expansion strategy. Journal of World Business, 51(3), 438-450. http://dx.doi.org/10.1016/j.jwb.2015.12.001

Kono, T. (1994). Changing a Company's Strategy and Culture. Long Range Planning, 27, 85-97. http://dx.doi.org/10.1016/0024-6301(94)90230-5

Lo, F. (2016). Intra-MNE advantage transfer and subsidiary innovativeness: The moderating effect of international diversification. Journal of Business Research, 69(5), 1712-1717. http://dx.doi.org/10.1016/j.jbusres.2015.10.043

Martin, R. P. (1991). Bulfinch's Mythology. New York, NY: Harper Collins Publishers.

Michailova, S., Z., Mustaffa, J., \& Barner-Rasmussen, W. (2016). Subsidiaries of Multinational Corporations. Journal of Leadership \& Organizational Studies, 23(2), 116-127. http://dx.doi.org/10.1177/1548051816633071

Morgan, M. J. (1993). How Corporate Culture Drives Strategy. Long Range Planning, 26, $110-118$. http://dx.doi.org/10.1016/0024-6301(93)90142-3

O'Reilly, III, C. A., Chatman, J., \& Caldwell, D. F. (1991). People and Organizational Culture: A Profile Comparison Approach to Assessing Person-Organization Fit. Academy of Management Journal, September, 487-516. 
http://dx.doi.org/10.2307/256404

Prabhupada, A. C., \& Bhaktivedanta, S. (1978). Srimad Bhagavtam, Second Canto, Los Angeles, CA: International Society for Krishna Consciousness.

Reger, R. K. (1994). Creating Earthquakes to Change Organizational Mindset. Academy of Management Executive, November, 8(4), 31-46.

Rice, E. (1978). Ten Religions of the East, New York, NY: Four Winds Press.

Schein, E. H. (1985). Defining Organizational Culture. Organization Culture and Leadership, 1-22.

Trice, H. M., \& Beyer, J. M. (1993). Changing Organizational Cultures. The Cultures of Work Organizations, 393-428.

Notes

Note 1. For the purposes of this article, the term, "MNC" is generically used to indicate an organization which has significant operations across many countries, whether an organization is categorized, according to their definitions, to be an exporting domestically-oriented firm, or an international, multi-domestic, multinational, global, or transnational firm. The reason for overlooking these definitional distinctions is to focus on the issues of the article without getting into the distinctions of the type of international organization involved in the issues since the issues apply to all types of international organizations.

Note 2. The possible patterns of an international organization's increasing internationalization process are reviewed here. International organizations often grow with specific pattern in mind, such as focusing on similar cultures as its home country culture, or, where competition is less, or, where economic and political climate is favorable, or, where there are many reputable local firms for opportunities of licensing, partnerships, joint venture and strategic alliances, or, where there are lower labor and total manufacturing costs, or, where there are tax breaks, or, where there are expanding markets, or, where there are market potential in other countries in the region, or, where there are vast raw materials availability, or, where there are newer technologies emerging for newer marketable products, or, where there are other international organizations which provide a global platform for launching newer products and services for comprising a fuller line of products and services that hitherto is not possible. In so expanding into other countries, the international organization fosters a spirit of cosmopolitan organizational culture. Such an approach says much about the organization: the best people are selected for the roles in the international organization, whether they are from the same host country, or from a nearby country, or from a faraway country, or from the international organization's home country. As the international organization grow, it seeks to foster a global culture that treats all peoples of all cultures and backgrounds fairly, equitably and equally. Such a reputation would then attract future talents that have a strong appreciation for a cosmopolitan spirit. Global values of the organization would precede its entry into newer country and regional markets.

\section{(c) EY}

This work is licensed under a Creative Commons Attribution 3.0 License. 